\title{
Synergistic Cancer Growth-Inhibitory Effect of Emodin and Low-Dose Cisplatin on Gastric Cancer Cells In vitro
}

\author{
Ling Huang ${ }^{1 *}$, Xin-Bao Wang ${ }^{1}$, Qi-Ming $\mathrm{Yu}^{1}$, Qing-Ying Luo ${ }^{2}$ and Zun-Zhen \\ Zhang ${ }^{2 *}$ \\ ${ }^{1}$ Department of Abdominal Surgery, Zhejiang Cancer Hospital, Hangzhou 310022, ${ }^{2}$ Department of Environmental Health, West \\ China School of Public Health, Sichuan University, Chengdu 610041, China
}

*For correspondence: Email: zhangzunzhen819@gmail.com, huangling632@126.com; Tel/Fax: 0086-571-88122233

\begin{abstract}
Purpose: To investigate the anti-cancer activity of emodin and its combination with low-dose cisplatin against human gastric cancer (SNU-5), including their effects on cell cycle phase distribution, apoptosis and cancer cell morphology.

Methods: The anti-cancer activity of emodin, cisplatin and their combination against human gastric cancer (SNU-5) cells was evaluated by 3-(4,5-Dimethylthiazol-2-yl)-2,5 diphenyltetra -zolium bromide (MTT) assay. Flow cytometry, using propidium iodide as a staining agent, was employed to study their effect on cell cycle phase distribution. Apoptosis induced by emodin and cisplatin was evaluated by annexin V binding assay using a flow cytometer. Alterations in cell morphology following apoptosis were studied by both fluorescence and transmission electron microscopy.

Results: Emodin induced a dose-dependent growth inhibitory effect on human gastric cancer cells in vitro. Furthermore, the combination of $25 \mu \mathrm{M}$ emodin $+3.0 \mu \mathrm{M}$ cisplatin induced relatively higher inhibitory effect (98\%) on these cells, indicating a synergistic enhancement of the anticancer activity of cisplatin. The combined effect of emodin and cisplatin also resulted in significant apoptosis induction as well as cell cycle arrest in comparison to the individual treatment by emodin (G2/M population of 14.82 $\%)$ or cisplatin (G2/M population - $36.20 \%$ ) Fluorescence and transmission electron microscopy also revealed that combination of emodin with cisplatin resulted in promounced apoptosis induction as well as cell morphology alterations. The percentage of early as well as late apoptotic cells was higher for the combination treatment than for the individual treatment by emodin or cisplatin.

Conclusion: Emodin synergistically enhances the anti-cancer activity of cisplatin in human gastric cancer (SNU-5) cells by inducing apoptosis as well as cell cycle arrest, thus paving way for improved chemotherapy in cancer.
\end{abstract}

Keywords: Gastric cancer, Emodin, CisplatinApoptosis, Flow cytometry, Cell cycle arrest

Tropical Journal of Pharmaceutical Research is indexed by Science Citation Index (SciSearch), Scopus, International Pharmaceutical Abstract, Chemical Abstracts, Embase, Index Copernicus, EBSCO, African Index Medicus, JournalSeek, Journal Citation Reports/Science Edition, Directory of Open Access Journals (DOAJ), African Journal Online, Bioline International, Open-J-Gate and Pharmacy Abstracts

\section{INTRODUCTION}

Gastric cancer (stomach cancer) is the second leading cause of cancer-related deaths worldwide after lung cancer [1,2]. China is one of the countries with the highest incidence of gastric cancer, and accounts for over $40 \%$ of all new gastric cancer cases in the world. Gastric cancer is the third leading cause of cancer mortality in China. Gastric cancer in Chinese patients is different from that occurring in the West, and is a significant health burden. In contrast, the incidence of gastric cancer is low in North 
America, Oceania, Northern Europe, Southeast Asia and Southern Asia [3].

Although various advances have arisen in gastric cancer management, patient prognosis remains very poor. Chemotherapy remains the backbone of treatments of gastric cancer and cisplatin is one of the most extensively used first line chemotherapeutic agents for gastric cancer [4]. However, these therapeutic strategies are insufficient due to severe side effects experienced by patients and drug resistance. As a result, it is important to find novel agents that can be used to enhance the anti-cancer effects of common chemotherapeutic drugs currently being used for gastric cancer treatment $[4,5]$.

Drug combination therapies are common practice in the treatment of cancer. Currently, cisplatin is the most active chemotherapeutic agent for the treatment of gastric cancer and is frequently combined with other agents such as docetaxel, gemcitabine and paclitaxel [6]. However, its use is restricted due to harmful side effects such as anemia, neurotoxicity, nephrotoxicity and the issues of drug resistance $[7,8]$. To address these problems, studies have been done on identifying novel agents that can be combined with cisplatin to increase the therapeutic efficacy and decrease side effects. Various published reports claim that numerous natural compounds can be combined with cisplatin with enhanced anti-cancer effects $[9,11]$, and decreased side effects since efficiency can be achieved with lower doses.

Therefore, the objective of the present study was to evaluate the effect of combining emodin, a natural compound extracted from various Rheum medicinal plant species, with cisplatin on human gastric carcinoma cell line (SNU-5) in vitro.

\section{EXPERIMENTAL}

\section{Reagents and chemicals}

Emodin and cisplatin were purchased from Sigma Chemical Company (St Louis, MO, USA). Growth medium RPMI-1640 (Hangzhou Sijiqing Biological Products Co, Ltd, China), Minimum Essential Medium (MEM, Invitrogen Corp., Carlsbad, CA, USA), Fetal Calf Serum (Gibco Corp, Carlsbad, CA, USA), trypsin, penicillin, 3(4,5-Dimethylthiazol-2-yl)diphenyltetrazolium bromide, a tetrazole MTT, streptomycin, Dimethysulphoxide DMSO and phosphate buffered saline (PBS, Sigma) were used in this study. MTT kit was obtained from Roche (USA). V-FITC-Propidium lodide
Apoptosis Detection Kit was purchased from Sigma (USA). All other chemicals and solvents used were of the highest purity grade.

\section{Cell line}

Human gastric carcinoma cell line (SNU-5) was procured from the China Center for Type Culture Collection (Wuhan, China) and grown in a humidified $5 \% \mathrm{CO}_{2}$ atmosphere at $37{ }^{\circ} \mathrm{C}$ in an incubator, and cultured in RPMI-1640 medium supplemented with $10 \%$ heat-inactivated newborn calf serum, $100 \mathrm{IU} / \mathrm{mL}$ penicillin and $100 \mu \mathrm{g} / \mathrm{mL}$ streptomycin.

\section{MTT cell viability assay}

Inhibition of cell proliferation was determined using a MTT (3-(4, 5-dimethylthiazol-2-yl)-2, 5diphenyltetrazolium bromide) assay. SNU-5 cells were seeded in a 96 multi-well plate $\left(6 \times 10^{2}\right.$ cells $/ 100 \mu \mathrm{L})$, and incubated at $37{ }^{\circ} \mathrm{C}$ for $12 \mathrm{~h}$. The next day, the cells were treated with $0,5,10$, 20, 40 and $80 \mu \mathrm{M}$ emodin; $3.0 \mu \mathrm{M}$ cisplatin or their combination $(25 \mu \mathrm{M}$ emodin $+3.0 \mu \mathrm{M}$ cisplatin) for $48 \mathrm{~h}$. After incubation, MTT reagent $(1.0 \mathrm{mg} / \mathrm{mL})$ was added to each well, and the plates were incubated in the dark at $37^{\circ} \mathrm{C}$ for 2 $\mathrm{h}$. The medium was removed and formazan was dissolved in DMSO, and the optical density was measured at $570 \mathrm{~nm}$ using an ELISA plate reader. The absorbance correlates with the viability of cells; therefore, \% viable cells (in relation to control) was calculated using Eq 1.

Viable cells $(\%)=\{(\mathrm{At}-\mathrm{Ac}) / \mathrm{Ac}\} 100$

where At and Ac are the absorbance of cells treated with test compound and of control cells, respectively.

The control was SNU-5 cells without emodin or cisplatin or their combination treatment. Cytotoxicity was expressed as the concentration of emodin/cisplatin that inhibited cell growth by $50 \%\left(\mathrm{IC}_{50}\right)$.

\section{Detection of apoptosis by fluorescence microscopy}

SNU-5 cell suspensions at a concentration of $10^{5}$ cells $/ \mathrm{mL}$ were taken in a Petri dish and treated with $25 \mu \mathrm{M}$ emodin, $3.0 \mu \mathrm{M}$ cisplatin or their combination for $48 \mathrm{~h}$. To distinguish the living cells from apoptotic and dead cells, they were washed with PBS and stained with a combination of acridine orange $(50 \mu \mathrm{g} / \mathrm{mL})$ : ethidium bromide $(50 \mu \mathrm{g} / \mathrm{mL}) 1: 1$ ratio for $20 \mathrm{~min}$ and $20 \mu \mathrm{L}$ of the cell suspension was taken on a slide and images were scanned [12] using a fluorescence 
microscope (magnification, x400; Nikon, Tokyo, Japan).

\section{Cell cycle analysis}

Human gastric carcinoma cell line (SNU-5) $(1 \times$ $10^{6}$ ) were seeded in $60-\mathrm{mm}$ dishes and treated with $25 \mu \mathrm{M}$ emodin, $3.0 \mu \mathrm{M}$ cisplatin or their combination for $48 \mathrm{~h}$. Floating and adherent cells were trypsinized and washed three times with PBS. Cells were incubated in $70 \%$ ethanol at -20 ${ }^{\circ} \mathrm{C}$ overnight, treated with $20 \mu \mathrm{g} / \mathrm{mL}$ RNase A, then stained with $5.0 \mu \mathrm{g} / \mathrm{mL}$ of propidium iodide. Finally the stained cells were analyzed and studied by flow cytometry at wavelength of 488 nm (FACS Calibur instrument (BD Biosciences, San Jose, CA, USA) equipped with Cell Quest 3.3 software).

\section{Annexin V/PI flow cytometric analysis}

Apoptotic rates were determined by flow cytometry using an Annexin V FITC apoptosis kit. The SNU- 5 cells were seeded at a density of $1 x$ $10^{5}$ cells per well in 6 well plates overnight and then treated with $25 \mu \mathrm{M}$ emodin, $3.0 \mu \mathrm{M}$ cisplatin or their combination for $48 \mathrm{~h}$. Cells were collected by centrifugation and washed twice with cold PBS. Staining was performed according to the manufacturer's instructions and the cells were analyzed using a FACScan flow cytometer (FACS Calibur instrument (BD Biosciences, San Jose, CA, USA) equipped with Cell Quest 3.3 software).

\section{Transmission electron microscopy (TEM)}

Human gastric carcinoma cell line (SNU-5) were seeded and grown at $5 \times 10^{5} / \mathrm{mL}$ in three flasks.
Cells, after treatment with $25 \mu \mathrm{M}$ emodin, $3.0 \mu \mathrm{M}$ cisplatin or their combination for $48 \mathrm{~h}$, were harvested and washed with PBS twice, and then added to $2.5 \%$ glutaraldehyde fixative for microtome sectioning using ultra microtome (LKB-V; JEOL Co; Japan). TEM was performed with a Transmission Electron Microscope (JEM2000EX, JEOL Co, Japan).

\section{Statistical analysis}

The experiments were performed in triplicate. Data are expressed as mean \pm standard deviation (SD). Statistical correlation of data was checked for significance by ANOVA and Student's $\mathrm{t}$ test. $P<0.05$ was considered statistically significant.

\section{RESULTS}

\section{Combined effect of emodin and cisplatin on human gastric cancer cell (SNU-5) viability}

Emodin and cisplatin induced a growth inhibitory effect on these cells in a dose-dependent manner (Fig 1).

Based on these findings, we were able to select a moderate dose $(25 \mu \mathrm{M}$ emodin $+3.0 \mu \mathrm{M}$ cisplatin) for combination treatment. The combination experiment revealed that as compared to monotherapy by emodin or cisplatin, combination of these two inhibited cancer cell growth much more significantly (Fig 2).

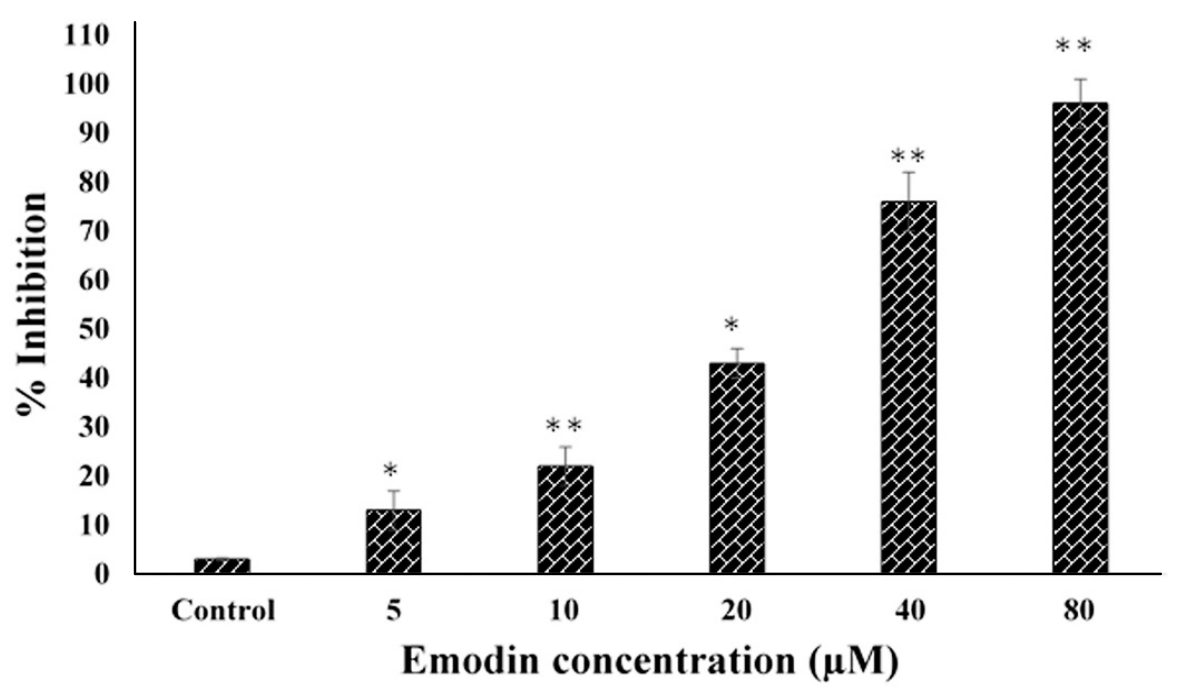

Figure 1: Effect of emodin on the cell viability of human gastric cancer cell (SNU-5) at different concentrations; ${ }^{*} p$ $<0.05$ vs. control group; ${ }^{* *} p<0.01$ vs. control group 
Joint effect of emodin and cisplatin on human gastric cancer cell (SNU-5) apoptosis

Condensation of chro matin, nuclear fragmentations and apoptotic bodies were clearly identified in treated cells (Fig 3A - D). Compared with monotherapy, apoptotic cells significantly increased in the combination treatment. Figure $3 \mathrm{~B}$ represents $25 \mu \mathrm{M}$ emodin, Figure $3 \mathrm{C}$ shows $3.0 \mu \mathrm{M}$ cisplatin while Figure 3D shows the effect of their combination. Figure $3 \mathrm{~A}$ represents control cells.

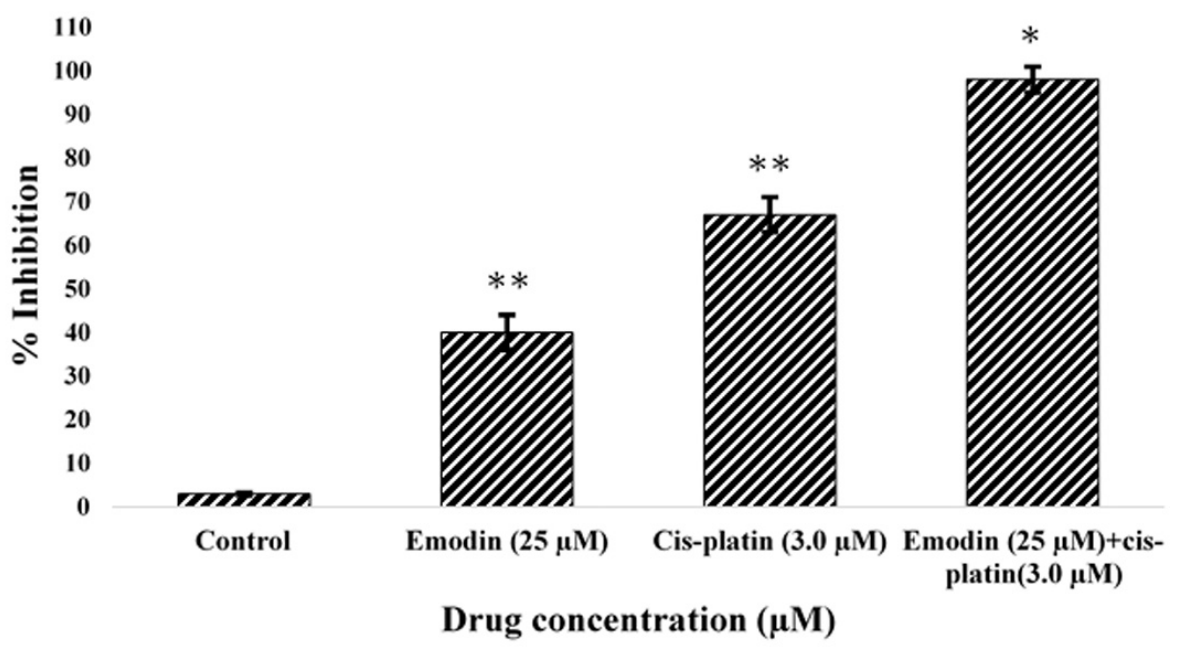

Figure 2: Combined effect of emodin and cisplatin on human gastric cancer cell (SNU-5) proliferation; * $p<0.05$ vs. control group; ${ }^{* *} p<0.01$ vs. control group
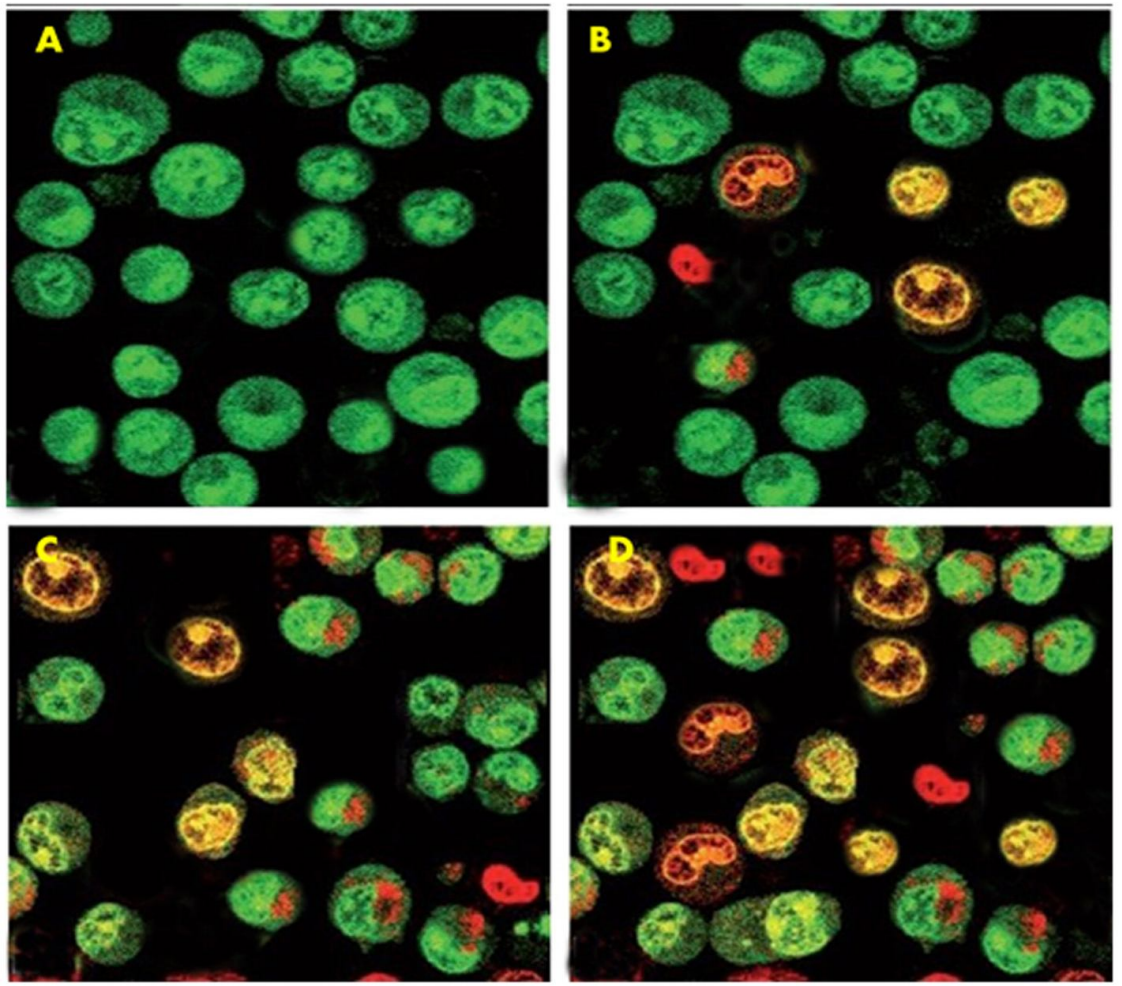

Figure 3: Combined effect of emodin and cisplatin on cell apoptosis observed by ETBR/AO staining using fluorescence microscopy. Human gastric cancer cells (SNU-5) were treated with (B) $25 \mu \mathrm{M}$ emodin, (C) $3.0 \mu \mathrm{M}$ cisplatin or (D) their combination for $48 \mathrm{~h}$. (A) shows the control (untreated) group, treated cells exhibited chromatin condensation, nuclear fragmentation and apoptotic bodies. The effect was much more in combination treatment as can be seen in the figure 
The effect of combination treatment on apoptosis induction in these cells was further demonstrated by Annexin V/PI staining. As can be seen in Fig $4 \mathrm{~B}$ and $\mathrm{C}$, emodin and cisplatin alone induced apoptosis because the percentage of early and late apoptotic cells increased compared to the control cells. Compared with monotherapy, the percentage of apoptotic cells induced by their combination was significantly higher (Fig 4D).

Joint effect of emodin and cisplatin on cell cycle phase distribution in human gastric cancer cells (SNU-5)

The effect of emodin, cisplatin and their combination on the cell cycle phase distribution in human gastric cancer cells is shown in Fig $5 \mathrm{~A}$ - D. Emodin (Fig 5B), cisplatin (Fig 5C) as well as their combination (Fig 5D) induced a G2/M cell cycle arrest. The percentage of G2/M population increased in the rank order: emodin < cisplatin < emodin + cisplatin. The highest percentage of
G2/M population (48.98 \%) was produced by the combination treatment.

\section{Combined effect of emodin and cisplatin on human gastric cancer cell apoptosis as revealed by transmission electron microscopy (TEM)}

Under the observation of transmission electron microscope, human gastric cancer cells were round and regular, with abundant organelles and normal double-membrane nuclei (Fig 6A). After exposing to emodin, cisplatin and their combination for $48 \mathrm{~h}$, early stage apoptosis could be observed (Fig 6B). Here again the effect was much more significant in combination (Fig 6D) as compared to emodin (Fig 6B) or cisplatin (Fig 6C). Nuclear membrane was domed outward with a sharp angle, and the nuclei chromatin was concentrated and clustered on the inner border of karyotheca. The endoplasmic reticulum became dilated in the inner segment.

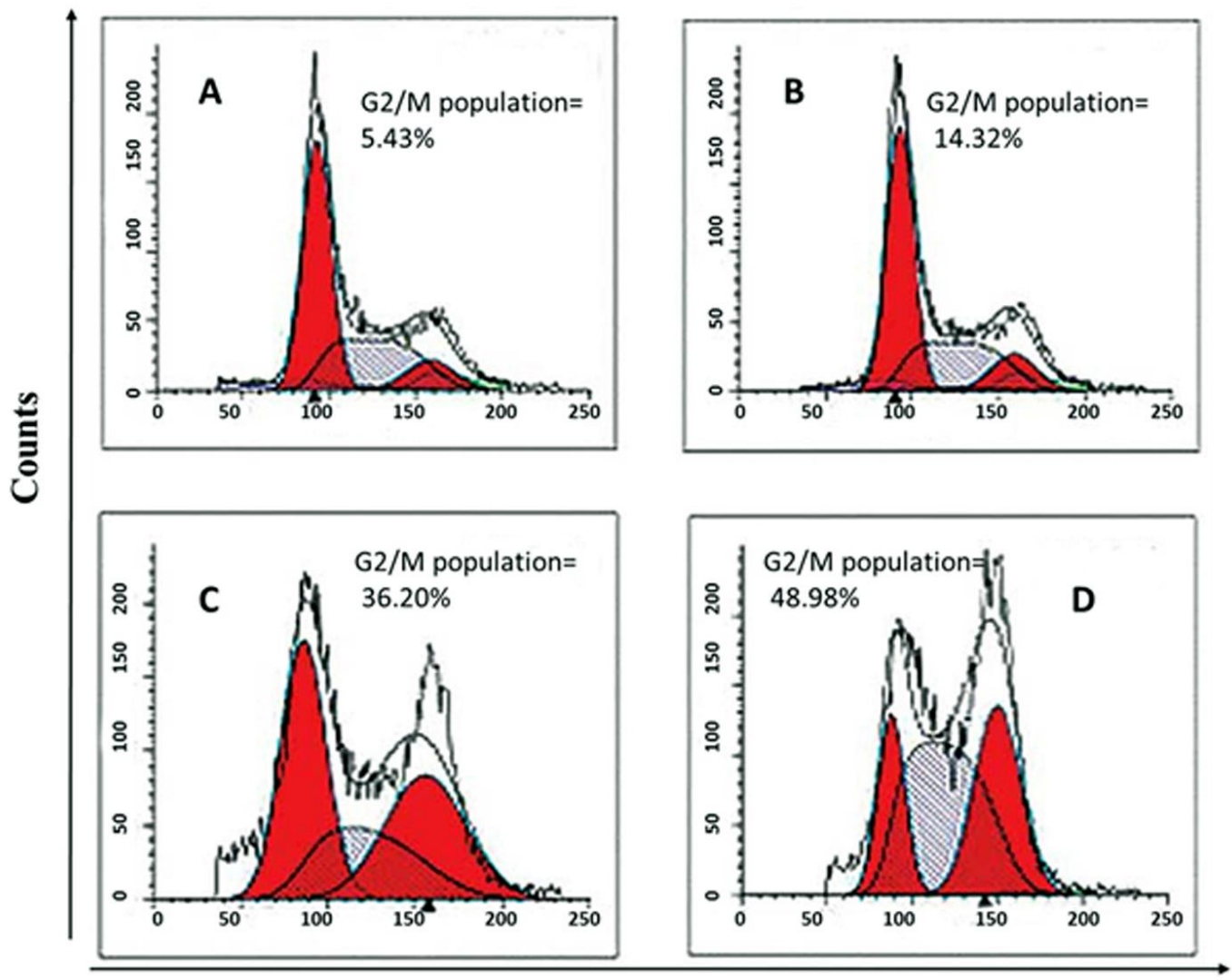

DNA content

Figure 4: Combined effect of emodin and cisplatin on the cell cycle arrest in human gastric cancer cells (SNU-5). Human gastric cancer cells (SNU-5) were treated with (B) $25 \mu \mathrm{M}$ emodin, (C) $3.0 \mu \mathrm{M}$ cisplatin or (D) their combination for $48 \mathrm{~h}$. (A) shows the control (untreated) group. Emodin, cisplatin as well as their combination induced a G2/M cell cycle arrest in these cells. But the effect of the combination on the G2/M population was much more prominent in case of combination treatment $(D)$ in comparison to emodin $(B)$ or cisplatin $(C)$ 


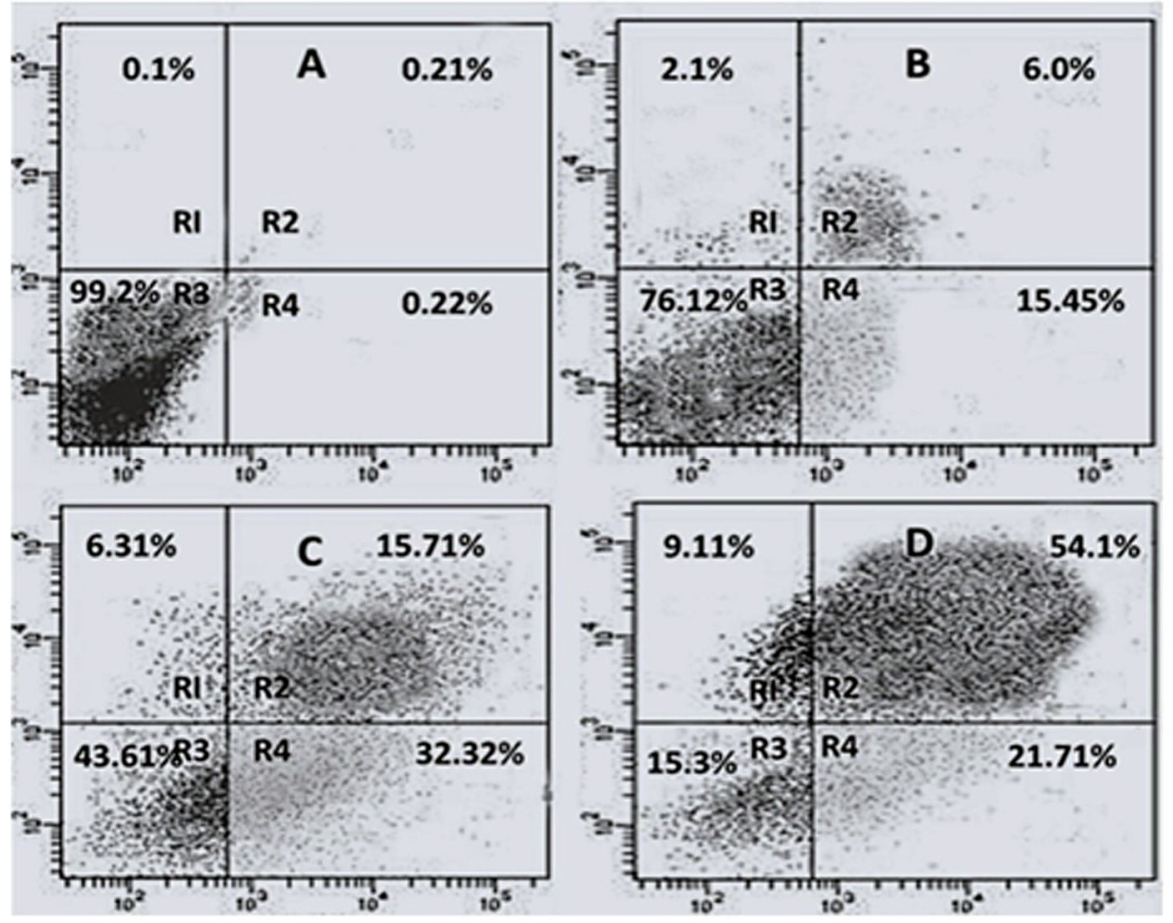

Figure 5: Combined effect of emodin and cisplatin on the apoptosis induction in human gastric cancer cells. SNU-5 cells were treated with (B) $25 \mu \mathrm{M}$ emodin, (C) $3.0 \mu \mathrm{M}$ cisplatin or (D) their combination for $48 \mathrm{~h}$. (A) shows the control (untreated) group. Normal healthy, early apoptotic, late apoptotic and dead/necrotic cell populations are shown as percentage of total cells in the quadrants R3, R4, R2 and R1, respectively. Combination treatment induced a potent apoptosis in these cells as compared to monotherapy

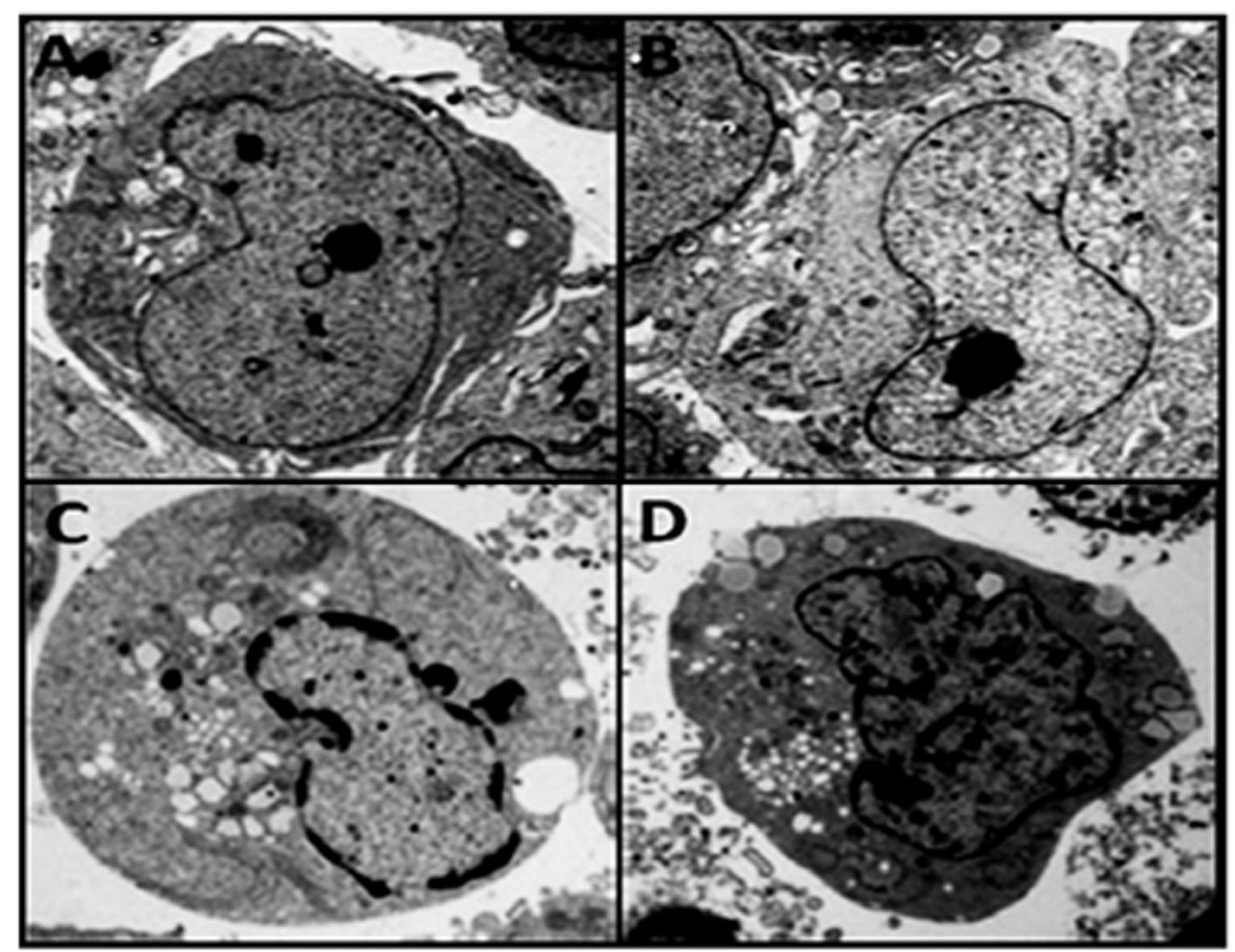

Figure 6: Combined effect of emodin and cisplatin on cell apoptosis observed by transmission electron microscopy (TEM). Human gastric cancer cells (SNU-5) were treated with (B) $25 \mu \mathrm{M}$ emodin, (C) $3.0 \mu \mathrm{M}$ cisplatin or (D) their combination for $48 \mathrm{~h}$. (A) shows the control (untreated) group 


\section{DISCUSSION}

Various previously published reports claim that emodin has cytotoxic activity against leukemia and murine leukemia [13]. Emodin was also reported to be cytotoxic to FM3A, a mouse mammary carcinoma cell line [14]. In addition, emodin has been found to show cytotoxic effects against human oral squamous cell carcinoma (HSC-2) and salivary gland tumor (HSG) cell lines than against normal human gingival fibroblasts(HGF) [15]. Cell viability test showed that inhibitory effect of emodin on numerous tumor cell lines was not through direct cytotoxicity [16].

Several mechanisms have been described as the possible modes of antitumor action of emodin. Inhibition of electron transport chain and uncoupling effects were recognized in rat mitochondria. Another mechanism involves electron transfer from the emodin (since it is good electron donor/acceptor) to molecular oxygen leading to the generation of the superoxide anion $\left(\mathrm{O}^{-2}\right)$ from which a diversity of ROS may be generated [17]. In the current study, emodin in combination with cisplatin exerted a greater anticancer effect than emodin or cisplatin alone.

Moreover, antiproliferative activity of emodin was presumed to be as a result of its effects on interfering with the progress of cell cycle in a variety of cells including human fibroblasts, smooth muscle cells, endothelial cells, and malignant cells [18-20]. Alkylation of DNA or other cell constituents has also been thought to be the primary lesion(s) leading to perturbation of the cell cycle. Emodin exhibited growthsuppressing effect on HepG2/C3A, PLC/PRF/5, and SK-HEP-1 hepatoma cells, by the sub-G1 accumulation, G2/M phase arrest. Thus, emodin displays effective inhibitory effects on the growth of various human hepatoma cell lines and stimulates the expression of p53 and p21 that resulted in the cell cycle arrest of HepG2/C3A cells at G2/M phase [21].Our study provides further support to the claim that combination treatment results in activity enhancement at a lower dose of the drug. Emodin could act as a bioenhancer to cisplatin in cancer chemotherapy.

\section{CONCLUSION}

The results indicate that emodin enhances the anticancer activity of cisplatin against human gastric cancer (SNU-5) cell line. It also enhances its tendency to induce apoptosis as well as cell cycle arrest. The significance of this finding lies in the fact that the anti-cancer efficacy of cisplatin has been reported to have become ineffective due to drug resistance. Combining it with emodin restores its ant-cancer efficacy. Further, the combination of emodin with cisplatin can result in less severe side-effects due to the low dose of the latter in the combination therapy.

\section{REFERENCES}

1. Alberts $S R$, Cervantes A, van de Velde CJ. Gastric cancer: epidemiology, pathology and treatment. Ann Oncol 2003; 14(2): ii31-36.

2. Wu B, Zhang $Q$, Shen $W$, Zhu J. Anti-proliferative and chemosensitizing effects of luteolin on human gastric cancer AGS cell line. Mol Cell Biochem 2008; 313(12): $125-132$.

3. Sun X, Mu R, Zhou Y, Dai X, Qiao Y, Zhang S, Huangfu X, Sun J, Li L, Lu F. 1990-1992 mortality of stomach cancer in China. Zhonghua Zhong Liu Za Zhi 2002; 24(1): 4-8.

4. Ajani JA. Evolving chemotherapy for advanced gastric cancer. Oncologist 2005; 10(3):49-58.

5. Van Cutsem E. The treatment of advanced gastric cancer: new findings on the activity of the taxanes. Oncologist 2004; 9(2):9-15.

6. Schiller JH, Harrington D, Belani CP, Langer C, Sandler A, Krook J, Zhu J, Johnson DH. Eastern Cooperative Oncology Group. Comparison of four chemotherapy regimens for advanced non-small-cell lung cancer. $N$ Engl J Med 2002; 346(2): 92-98.

7. Douillard JY, Eckardt J, Scagliotti GV. Challenging the platinum combinations in the chemotherapy of NSCLC. Lung Cancer 2002; 38 (4): 21-28.

8. Stewart DJ. Mechanisms of resistance to cisplatin and carboplatin. Crit Rev Oncol Hematol 2007; 63(1): 1231.

9. Zhang $Y$, Wang $C$, Wang $H$, Wang $K$, Du $Y$, Zhang J. Combination of Tetrandrine with cisplatin enhances cytotoxicity through growth suppression and apoptosis in ovarian cancer in vitro and in vivo. Cancer Lett 2011; 304(1): 21-32.

10. Duarte VM, Han E, Veena MS, Salvado A, Suh JD, Liang $L J$, Faull KF, Srivatsan ES, Wang MB. Curcumin enhances the effect of cisplatin in suppression of head and neck squamous cell carcinoma via inhibition of IKK $\beta$ protein of the NFKB pathway. Mol Cancer Ther 2010; 9(10): 2665-2675.

11. Jafri SH, Glass J, Shi $R$, Zhang $S$, Prince $M$, KleinerHancock $H$. Thymoquinone and cisplatin as a therapeutic combination in lung cancer: In vitro and in vivo. J Exp Clin Cancer Res 2010; 29: 87.

12. Gorman A, McCarthy J, Finucane D, Reville W, Cotter $T$. Morphological assessment of apoptosis. In: Cotter TG, Martin SJ, editors. Techniques in Apoptosis. A user's guide. New York: Portland Press; 1994. 333 p.

13. Sato M, Maulik G, Bagchi D, Das DK. Myocardial protection by protykin, a novel extract of trans

Trop J Pharm Res, August 2015; 14(8): 1433 
resveratrol and emodin. Free Radic Res 2000; 32(2):135-144.

14. Kuo YC, Tsai WJ, Meng HC, Chen WP, Yang LY, Lin CY. Immune reponses in human mesangial cells regulated by emodin from Polygonum hypoleucum Ohwi. Life Sci 2001; 68(11):1271-1286.

15. Lee $H$, Tsai SJ. Effect of emodin on cooked-food mutagen activation. Food Chem Toxicol 1991; 29(11):765-770.

16. Wells JM, Cole RJ, Kirksey JW. Emodin, a toxic metabolite of Aspergillus wentii isolated from weevildamaged chestnuts. Appl Microbiol 1975; 30(1):2628.

17. Shi YQ, Fukai T, Sakagami H, Kuroda J, Miyaoka R, Tamura M, Yoshida N, Nomura T. Cytotoxic and DNA damage-inducing activities of low molecular weight phenols from rhubarb. Anticancer Res2001; 21(4A):2847-2853.

18. Tsai TH. Analytical approaches for traditional chinese medicines exhibiting antineoplastic activity. J Chromatogr B Biomed Sci Appl 2001; 764(1-2):2748.

19. Demirezer LO, Kuruuzum-Uz A, Bergere I, Schiewe HJ, Zeeck $A$. The structures of antioxidant and cytotoxic agents from natural source: Anthraquinones and tannins from roots of Rumexpatientia. Phytochemistry 2001; 58(8):1213-1217.

20. Zhang L, Chang CJ, Bacus SS, Hung MC. Suppressed transformation and induced differentiation of HER2/neu-over expressing breast cancer cells by emodin. Cancer Res 1995; 55(17):3890-3896.

21. Lin CC, Chang $\mathrm{CH}$, Yang JJ, Namba T, Hattori $M$. Hepatoprotective effects of emodin from Ventilago leiocarpa. J Ethnopharmacol 1996; 52(2):107-111.

22. Yim TK, Wu WK, Mak DH, Ko KM. Myocardial protective effect of an anthraquinone-containing extract of Polygonum multiflorum ex vivo. Planta Med 1998;64(7):607-611.
23. Yagi $T$, Yamauchi K. Synergistic effects of anthraquinones on the purgative activity of rheinanthrone in mice. J Pharm Pharmacol 1999; 51(1):93-95.

24. Kawai K, Kato T, Mori H, Kitamura J, Nozawa Y. A comparative study on cytotoxicities and biochemical properties of anthraquinone mycotoxins emodin and skyrin from Penicillium islandicum Sopp. Toxicol Lett 1984; 20(2):155-160.

25. Morita H, Umeda M, Masuda T, Ueno Y. Cytotoxic and mutagenic effects of emodin on cultured mousecarcinoma FM3A cells. Mutat Res 1988; 204(2):329-332.

26. Shi YQ, Fukai T, Sakagami H, Kuroda J, Miyaoka R, Tamura M, Yoshida N, Nomura T. Cytotoxicand DNA damage-inducing activities of low molecular weight phenols from rhubarb. Anticancer Res 2001; 21(4A):2847-2853.

27. Kuo YC, Sun CM, Ou JC, Tsai WJ. A tumor cell growth inhibitor from Polygonum hypoleucum Ohwi. Life Sci 1997; 61(23):2335-2344.

28. Ubbink-Kok T, Anderson JA, Konings WN. Inhibition of electron transfer and uncoupling effects by emodin and emodinanthrone in Escherichia coli. Antimicrob Agents Chemother 1986; 30(1):147-151.

29. Guo $D, X u C$, Chen Y. A study on the effect of emodin on smooth muscle cell proliferation. Zhonghua Nei Ke Za Zhi 1996; 35(3):157-159.

30. Kamei H, Koide T, Kojima T, Hashimoto $Y$, Hasegawa $M$. Inhibition of cell growth in culture by quinones. Cancer Biother Radiopharm 1998; 13(3):185-188.

31. $Q u$ Y, Yao P, Li TQ. Effects of emodin on lung fibroblast proliferation and cell cycle in vitro. Sichuan Da Xue Xue Bao Yi Xue Ban 2004; 35(1):74-76.

32. Liu JB, Gao XG, Lian T, Zhao AZ, Li KZ. Apoptosis of human hepatoma HepG2 cells induced by emodinin vitro. Ai Zheng 2003; 22(12):1280-1283. 